\title{
Estudo da atividade de uma 4-fenil cumarina na diferenciação de linfócitos Th17 no desenvolvimento da doença periodontal.
}

\section{Murilo César Paraluppi*, Pedro Luiz Rosalen, Douglas da Silva Prado, Thaise Mayumi Taira, Severino Matias de Alencar, Sandra Yasuyo Fukada Alves, Thiago Mattar Cunha, Marcelo Franchin.}

\section{Resumo}

No presente estudo, foi avaliada a atividade do cinamoiloxi-mammeisina (CNM), uma 4-fenil cumarina isolada da geoprópolis brasileira, sobre a diferenciação de linfócitos Th17 no desenvolvimento da doença periodontal. De acordo com os resultados, a administração do CNM, reduziu a reabsorção óssea dos camundongos com periodontite induzida por ligadura, bem como a frequência de linfócitos Th17 nos linfonodos maxilares. Espera-se que as informações obtidas neste estudo contribuam para o desenvolvimento de uma nova droga no tratamento da doença periodontal.

Palavras-chave: própolis, doença periodontal, linfócitos Th17.

\section{Introdução}

A doença periodontal é caracterizada por uma resposta inflamatória de origem bacteriana nos tecidos responsáveis pela sustentação e proteção dos dentes. ${ }^{1-2}$ Dentre os principais tipos celulares envolvidos, destaca-se os linfócitos $\mathrm{T}$ helper 17 (Th17) que apresentam papel chave no desenvolvimento da doença periodontal, devido aos seus efeitos pró-inflamatórios. ${ }^{3-5}$

Estudos do nosso grupo de pesquisa isolou o composto cinamoiloxi-mammeisina (CNM), uma 4-fenil cumarina presente na geoprópolis de Melipona scutellaris ${ }^{6}$. Além disso, nossos estudos constataram um promissor efeito anti-inflamatório do $\mathrm{CNM}^{7}$, entretanto, a sua atividade sobre os linfócitos Th17 e desenvolvimento da doença periodontal, nunca foi estudada.

Assim, no presente estudo investigou-se a atividade e mecanismo de ação do CNM no desenvolvimento da periodontite experimental.

\section{Resultados e Discussão}

Inicialmente foi realizado 0 isolamento $e$ identificação do composto $\mathrm{CNM}^{6}$ e sua estrutura química está apresentada na Figura 1.

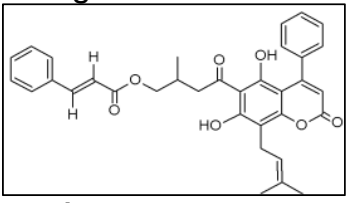

Figura 1. Estrutura química do cinamoiloxi-mammeisina.

Posterior ao isolamento, foi avaliada a atividade do CNM no desenvolvimento da doença periodontal induzida por ligadura (CEUA/FMRP-USP no 190/2018). Conforme os resultados (Figura 2), verificou-se que a administração subcutânea do composto CNM na dose de $100 \mu \mathrm{g} / \mathrm{kg}$, 1x/dia por 9 dias, reduziu a reabsorção óssea dos camundongos com periodontite $(\mathrm{p}<0,05)$.
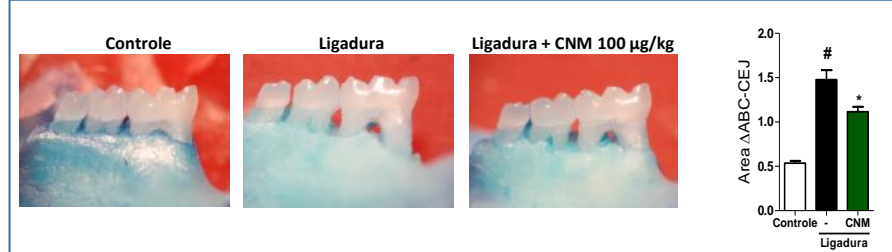

Figura 2. Efeito do CNM na doença periodontal. Dados expressos em média \pm EPM com $n=5$ por grupo. Símbolo indica diferença estatística ( $p<0,05$, Tukey's). \# comparado ao grupo controle; ${ }^{*}$ comparado ao grupo ligadura.
Em seguida, foi avaliada a atividade do CNM na diferenciação de linfócitos Th17 presente nos linfonodos maxilares de camundongos com periodontite. Conforme os resultados apresentados na Figura 3, verificou-se que a administração de CNM por 9 dias, reduziu a frequência de linfócitos Th17 de camundongos com periodontite $(p<0,05)$. Estes resultados demonstram, portanto, que a atividade inibitória do CNM na reabsorção óssea, deve-se em parte, pela redução da diferenciação dos linfócitos Th17, conforme verificado nos resultados deste estudo.

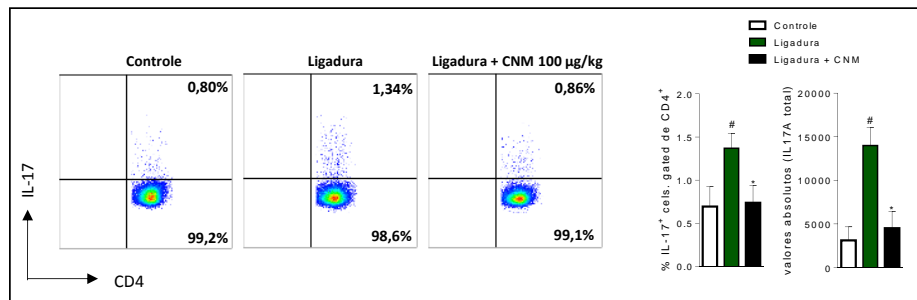

Figura 3. Efeito do CNM na frequência de linfócitos Th17 dos linfonodos maxilares de camundongos com periodontite. Dados expressos em média \pm EPM com $\mathrm{n}=5$ por grupo. Símbolo indica diferença estatística $(p<0,05$, Tukey's). \# comparado ao grupo controle; * comparado ao grupo ligadura.

\section{Conclusões}

O CNM reduziu o desenvolvimento da periodontite induzida por ligadura por supressão da diferenciação dos linfócitos Th17. Espera-se que as informações obtidas no presente estudo contribuam para o desenvolvimento de uma nova droga para o tratamento da doença periodontal.

\section{Agradecimentos}

PIBIC/CNPq e FAPESP (Processo número 2016/155639).

\footnotetext{
${ }^{1}$ Khalili, J. Lik. Sprava. 2008, (3-4), 21.

${ }^{2}$ Napimoga, M. H.; Da Silva, C. A.; Carregaro, V.; Farnesi-de-Assunção, T. S.; Duarte, P. M.; De Melo, N. F. e Fraceto, L. F. J. Immunol. 2012, 189, 1052.

${ }^{3}$ Noack, M. e Miossec, P. Autoimmun. Rev. 2014, 13, 677.

${ }^{4}$ Yang, J.; Sundrud, M. S.; Skepner, J. e Yamagata, T. Trends Pharmacol. Sci. 2014, 35, 500 .

${ }^{5}$ Wang, L.; Guan, N.; Jin, Y.; Lin, X. e Gao, H. Int. Immunopharmacol. 2015 $25,73$.

${ }^{6}$ Da Cunha, M. G.; Rosalen, P. L.; Franchin, M.; Alencar, S. M.; Ikegaki, M.; Ransom, T. e Beutler, J. A. Planta Med. 2016, 82, 194.

${ }^{7}$ Franchin, M.; Rosalen, P. L.; Cunha, M. G.; Silva R. L.; Colón, D. F.; Bassi, G. S.; Alencar, S. M.; Ikegaki, M.; Alves-Filho, J. C.; Cunha, F. Q.; Beutler, J. A. e Cunha, T. M. J. Nat. Prod. 2016, 79, 1833.
} 